\title{
Association of Enhancer of Zeste 2 (EZH2) Genotypes with Bladder Cancer Risk in Taiwan
}

\author{
WEN-SHIN CHANG ${ }^{1,2^{*}}$, CHENG-HSI LIAO $^{1,2,3,8^{*}}$, CHIA-WEN TSAI $^{2 *}$, PEI-SHIN HU ${ }^{2,4}$, HSI-CHIN WU $^{2}$, \\ SHIH-WEI HSU ${ }^{1,2,3,8}$, CHIEH-LUN HSIAO ${ }^{1,2}$, CHANG-HSIEN HSU $^{5}$, YI-WEN HUNG ${ }^{6}$ and DA-TIAN BAU ${ }^{1,2,7}$ \\ ${ }^{1}$ Graduate Institute of Clinical Medical Science, China Medical University, Taichung, Taiwan, R.O.C.; \\ ${ }^{2}$ Terry Fox Cancer Research Laboratory, China Medical University Hospital, Taichung, Taiwan, R.O.C.; \\ ${ }^{3}$ Taichung Armed Forces General Hospital, Taichung, Taiwan, R.O.C.; \\ ${ }^{4}$ Department of Ophthalmology, Changhua Christian Hospital, Changhua, Taiwan, R.O.C.; \\ Departments of ${ }^{5}$ Business Administration, and ${ }^{7}$ Bioinformatics and Medical Engineering, \\ Asia University, Taichung, Taiwan, R.O.C.; \\ ${ }^{6}$ Department of Medicine Research, Taichung Veterans General Hospital, Taichung, Taiwan, R.O.C.; \\ ${ }^{8}$ National Defence Medical Center, Taipei, Taiwan, R.O.C.
}

\begin{abstract}
Aim: Bladder cancer is the sixth most common cancer worldwide and its incidence is particularly high in many developed regions including southwestern Taiwan. However, the genetic contribution to the etiology of bladder cancer is not well-understood. The aim of this study was to evaluate the association of the enhancer of zeste homolog 2 (EZH2) genotypes with Taiwan bladder cancer risk. Materials and Methods: Three polymorphic variants of EZH2 were analyzed regarding their association with bladder cancer risk, and three hundred and seventy-five patients with bladder cancer and same number of age-and gender-matched healthy controls recruited were genotyped by the PCR-RFLP method. Results: Among the three polymorphic sites examined, the genotypes of EZH2 rs887569 (C to T), but not rs41277434 (A to $C$ ) or rs3757441 ( $T$ to $C)$, were positively associated with bladder cancer risk ( $p$ for trend $=0.0146$ ). Individuals with the EZH2 rs887569 TT genotypes were associated with decreased cancer risk than those with wild-type CC genotype. The stratified analyses showed that EZH2 rs887569 TT genotypes had protective effects on non-smokers but obviously not on smokers. Conclusion: Our findings provide evidence that the $T$ allele of EZH2 rs887569 may be
\end{abstract}

*These Authors contributed equally to this study.

Correspondence to: Da-Tian Bau, Terry Fox Cancer Research Laboratory, China Medical University Hospital, 2 Yuh-Der Road, Taichung, 404 Taiwan, R.O.C. Tel: +886 422052121 Ext. 7534, e-mail: datian@mail.cmuh.org.tw; artbau2@gmail.com

Key Words: Bladder cancer, EZH2, genotype, polymorphism, Taiwan. associated with the lower risk of bladder cancer development, especially among non-smokers.

Bladder cancer is the most serious urinary neoplasm worldwide, with high incidence rates of approximately $10 / 100,000$ and 3/100,000 in more and less developed regions, respectively (1). According to the statistical data provided by the International Agency for Research on Cancer, there were an estimated 429,800 new cases of bladder cancer and 165,100 deaths occurred in 2012 worldwide $(1,2)$. In Taiwan, bladder cancer ranks seventh in incidence and mortality among common carcinomas (3). Carcinogenesis of cancer is a complex, multistep and multifactorial process being the result of interactions of lifestyle, environmental and genetic factors (3-8).

The enhancer of zeste homolog 2 (EZH2), embryonic ectoderm development (EED), and suppressor of zeste 12 homolog (SUZ12) are polycomb group proteins which are important epigenetic chromatin modifiers, cell-cycle regulators, and believed to be involved in carcinogenesis. EZH2 is reported to serve as a histone methyl transferase, playing a crucial role in methylation of $\mathrm{H} 3 \mathrm{~K} 27$ and recruiting of protein regulator of cytokinesis 1 (PRC1), leading to initiation of gene silencing (9-11). In the early twentieth century, EZH2 overexpression was firstly reported in hematological malignancies $(12,13)$. In recent years, an increasing number of studies have reported overexpression of EZH2 to be associated with poor prognosis in several types of cancers including oesophageal (14), breast (15), endometrial (16), gastric (17-21), colorectal (22, 23), hepatocellular (24), pancreatic (25) and oral (26) cancer.

In bladder cancer, the mRNA levels of $E Z H 2$ were found to be higher in bladder cancer specimens than non-tumor 
Table I. Primer sequences, polymerase chain reaction and restriction fragment length polymorphism (PCR-RFLP) conditions for the genotyping of enhancer of zeste homolog 2 (EZH2).

\begin{tabular}{llccc}
\hline Polymorphism & Primer sequences (5' to 3') & Restriction enzyme & Allele type & Product size (bp) \\
\hline rs887569 & F: 5'-TTGCATATTCAGGCTGGCCT-3' & Bsr I & C & 345 \\
& R: 5'-ATCAGGATGCTTAGGCCTGA-3' & & T & $185+160$ \\
rs41277434 & F: 5'-CTGGATGGCTCTCTTGGCAA -3' & Kpn I & A & C \\
rs3757441 & R: 5'-CCTGAAGAACTGTAACCAGT-3' & Direct sequencing & T & C \\
& F: 5'-TTGCATATTCAGGCTGGCCT-3' & & C \\
\hline
\end{tabular}

*F and $\mathrm{R}$ indicate forward and reverse primers, respectively.

bladder specimens, and EZH2 mRNA overexpression was detected in $100 \%$ of high-grade and invasive bladder tumors (27). However, the contribution of EZH2 genotypes to susceptibility for abnormal expression of EZH2 and bladder carcinogenesis is unknown. The current work focused on revealing the association of genotypes of EZH2 at rs887569 (C to $\mathrm{T}$ ), rs41277434 (A to $\mathrm{C}$ ) and $\operatorname{rs} 3757441$ ( $\mathrm{T}$ to $\mathrm{C}$ ) among 375 bladder cancer and 375 healthy controls in Taiwan, a highly genetically-conserved population.

\section{Materials and Methods}

Study population and sample collection. Our study was approved by the Institutional Review Board of China Medical University Hospital (DMR104-IRB-158), and all clinical investigations were conducted according to the principles expressed in the Declaration of Helsinki. Three hundred and seventy-five patients diagnosed with bladder cancer were enrolled at the outpatient clinics of general surgery between 2003 to 2009 at the China Medical University Hospital, Taichung, Taiwan, Republic of China. All patients who voluntarily participated completed a self-administered questionnaire and provided their peripheral blood samples. The clinical characteristics of patients including histological details were all graded and defined by expert surgeons. An equal number of non-cancer healthy controls were selected by matching for age and gender after initial random sampling from the Health Examination Cohort of the hospital. The exclusion criteria of the control group included previous malignancy, metastasized cancer from other or unknown origin, and any familial or genetic diseases. Both groups completed a short questionnaire which included personal habits. Smokers were defined as daily or almost daily smokers who had smoked at least five packs of cigarettes per year in their lifetime. Age of smoking initiation, whether they were currently smoking or had already quit, and if so, when they had quit, and on average, how many cigarettes they smoked or had smoked daily were recorded for smokers.

Genotyping conditions. Each participant provided 3-5 ml venous blood. Genomic DNA was prepared within two days from their peripheral blood leucocytes with the protocol of a QIAamp Blood Mini Kit (Blossom, Taipei, Taiwan) and further processed and stored according to our regular methodology (28-32). The polymerase chain reaction (PCR) cycling conditions for all the $E Z H 2$ genotyping work were: one cycle at $94^{\circ} \mathrm{C}$ for $5 \mathrm{~min} ; 35$ cycles of $94^{\circ} \mathrm{C}$ for $30 \mathrm{~s}, 55^{\circ} \mathrm{C}$ for $30 \mathrm{~s}$, and $72^{\circ} \mathrm{C}$ for $30 \mathrm{~s}$, and a final extension at $72^{\circ} \mathrm{C}$ for $10 \mathrm{~min}$ using BIO-RAD Mycycler PCR machine (BIO-RAD, Hercules, CA, USA). The primers for rs887569 and rs41277434 genotyping were all designed by our team, and the PCR primer sequences in addition to each responsive restriction enzyme for each DNA product are listed in Table I. Amplified and digested DNA products for rs887569 and rs41277434 were monitored by electrophoresis on 3\% agarose gels, stained with ethidium bromide and imaged under UV irradiation. The sequencing for rs 3757441 were $100 \%$ consistent between the results using forward and reverse primers.

Statistical analyses. Pearson's Chi-square test or Fisher's exact test (when the expected number in any cell was less than five) was used to compare the distribution of the EZH2 genotypic and allelic frequencies between case and control groups. The odds ratios (OR) together with $95 \%$ confidence intervals $(\mathrm{CI})$ were calculated to assess the relative risk conferred by a particular allele and genotype. Demographic and clinical data between groups were compared by Chi-square test and by Student's $t$-test. Data was assumed as significant at a statistical level when the $p$-value was less than 0.05 .

\section{Results}

The demographic characteristics of patients with bladder cancer and the non-cancer controls are summarized in Table II. There were no significant differences between groups regarding their age, gender, cigarette smoking and alcohol drinking status (Table II).

The analysis for the distribution frequencies of the genotypes and alleles of EZH2 rs887569 in the bladder cancer and control groups are summarized in Table III. Firstly, there was a significant difference between bladder cancer and control groups in the distribution of genotypic frequency ( $p$ for trend $=0.0146$ ), and the ORs for those with CT and TT genotype were $0.78(95 \% \mathrm{CI}=0.58-1.06)$ and $0.47(95 \% \mathrm{CI}=0.27-0.80)$ compared to that for those with the $\mathrm{CC}$ wild-type genotype. Secondly, we performed dominant and recessive comparisons, finding that the $\mathrm{ORs}$ of the $\mathrm{CC}+\mathrm{CT}$ versus $\mathrm{TT}$ and $\mathrm{CC}$ versus $\mathrm{CT}+\mathrm{TT}$ were $0.53(95 \% \mathrm{CI}=0.31-0.89, p=0.0212)$ and 0.72 (95\% CI=0.54-0.96, $p=0.0329$ ), respectively. Lastly, from the results of $E Z H 2$ rs887569 allelic frequency analysis, we found that people carrying the $\mathrm{T}$ allele appear to have a protective 
Table II. The demographic characteristics of investigated patients with bladder cancer and healthy controls.

\begin{tabular}{|c|c|c|c|c|c|c|c|}
\hline \multirow[t]{2}{*}{ Characteristic } & \multicolumn{3}{|c|}{ Controls $(n=375)$} & \multicolumn{3}{|c|}{ Cases $(n=375)$} & \multirow[t]{2}{*}{$p$-Value ${ }^{a}$} \\
\hline & $\mathrm{n}$ & $\%$ & Mean (SD) & $\mathrm{n}$ & $\%$ & Mean (SD) & \\
\hline Age (years) & & & $62.9(9.8)$ & & & $61.4(10.3)$ & 0.7315 \\
\hline Age group (years) & & & & & & & 0.7108 \\
\hline$\leq 55$ & 152 & $40.5 \%$ & & 158 & $42.1 \%$ & & \\
\hline$>55$ & 223 & $59.5 \%$ & & 217 & $57.9 \%$ & & \\
\hline Gender & & & & & & & 0.5525 \\
\hline Male & 287 & $76.5 \%$ & & 279 & $74.4 \%$ & & \\
\hline Female & 88 & $23.5 \%$ & & 96 & $25.6 \%$ & & \\
\hline \multicolumn{8}{|l|}{ Habit } \\
\hline Cigarette smoking & 186 & $49.6 \%$ & & 201 & $53.6 \%$ & & 0.3063 \\
\hline Alcohol drinking & 176 & $46.9 \%$ & & 189 & $50.4 \%$ & & 0.3807 \\
\hline \multicolumn{8}{|l|}{ Stage } \\
\hline Non-muscle-invasive & & & & 235 & $62.7 \%$ & & \\
\hline Muscle-invasive & & & & 140 & $37.3 \%$ & & \\
\hline \multicolumn{8}{|l|}{ Grade } \\
\hline Low & & & & 151 & $40.3 \%$ & & \\
\hline High & & & & 224 & $59.7 \%$ & & \\
\hline
\end{tabular}

aBased on Chi-square test with Yate's correction.

Table III. Distribution of the enhancer of zeste homolog 2 (EZH2) rs887569 genotypic and allelic frequencies among patients with bladder cancer and controls.

\begin{tabular}{|c|c|c|c|c|c|c|}
\hline \multirow{2}{*}{$\begin{array}{l}\text { rs887569 } \\
\text { Genotypic frequency }\end{array}$} & \multicolumn{2}{|c|}{ Controls } & \multicolumn{2}{|c|}{ Patients } & \multirow[b]{2}{*}{ OR $(95 \% \mathrm{CI})$} & \multirow[b]{2}{*}{$p$-Value ${ }^{a}$} \\
\hline & $\mathrm{n}$ & $\%$ & $\mathrm{n}$ & $\%$ & & \\
\hline $\mathrm{CC}$ & 150 & $40.0 \%$ & 180 & $48.0 \%$ & 1.00 (Reference) & \\
\hline $\mathrm{CT}$ & 182 & $48.5 \%$ & 171 & $45.6 \%$ & $0.78(0.58-1.06)$ & 0.1290 \\
\hline TT & 43 & $11.5 \%$ & 24 & $6.4 \%$ & $0.47(0.27-0.80)^{*}$ & $0.0078^{*}$ \\
\hline$p$ for trend & & & & & & $0.0146^{*}$ \\
\hline \multicolumn{7}{|l|}{ Carrier comparison } \\
\hline $\mathrm{CC}+\mathrm{CT}$ & 332 & $88.5 \%$ & 351 & $93.6 \%$ & 1.00 (Reference) & \\
\hline $\mathrm{TT}$ & 43 & $11.5 \%$ & 24 & $6.4 \%$ & $0.53(0.31-0.89)^{*}$ & $0.0212 *$ \\
\hline $\mathrm{CC}$ & 150 & $40.0 \%$ & 180 & $48.0 \%$ & 1.00 (Reference) & \\
\hline $\mathrm{CT}+\mathrm{TT}$ & 225 & $60.0 \%$ & 195 & $52.0 \%$ & $0.72(0.54-0.96)^{*}$ & $0.0329 *$ \\
\hline \multicolumn{7}{|l|}{ Allelic frequency } \\
\hline Allele C & 482 & $64.3 \%$ & 531 & $70.8 \%$ & 1.00 (Reference) & \\
\hline Allele T & 268 & $35.7 \%$ & 219 & $29.2 \%$ & $0.74(0.60-0.92)^{*}$ & $0.0069 *$ \\
\hline
\end{tabular}

OR: Odds ratio, CI: confidence interval; abased on Chi-square test with Yate's correction; *statistically significant.

effect, compared to those carrying an A allele (OR=0.74, 95\% $\mathrm{CI}=0.60-0.92, p=0.0069$ ) (Table III). For EZH2 rs41277434 (Table IV) and rs3757441 (Table V), there was no difference in the distribution of either genotypic or allelic frequencies between patient and control groups. The conclusive finding deduced from the results in Tables III-V is that the T allele of EZH2 rs887569 or TT genotype may serve as a protective biomarker for bladder cancer detection and prediction.

After finding that T-bearing genotypes of EZH2 rs887569 were associated with bladder cancer risk, we examined the interaction between the genotype of EZH2 rs887569 and cigarette smoking and alcohol drinking habits. The results showed that the genotypic distribution of CC, CT and TT at $E Z H 2$ rs887569 was significantly different between bladder cancer and control non-smokers ( $p$ for trend=0.0164) (Table VI). Consistent with the findings in Table III, the frequency of TT genotype was still significantly lower $(5.8 \%)$ in non-smoking patients with bladder cancer than those for control non-smokers (13.2\%). On the contrary, there was no such distribution difference in the smoking subgroups ( $p$ for trend $=0.9196$ ). There was no obvious interaction between the genotype of EZH2 rs887569 and personal alcohol drinking habits (data not shown). 
Table IV. Distribution of the enhancer of zeste homolog 2 (EZH2) rs41277434 genotypic and allelic frequencies among patients with bladder cancer and controls.

\begin{tabular}{|c|c|c|c|c|c|c|}
\hline \multirow{2}{*}{$\begin{array}{l}\text { rs41277434 } \\
\text { Genotypic frequency }\end{array}$} & \multicolumn{2}{|c|}{ Controls } & \multicolumn{2}{|c|}{ Patients } & \multirow[b]{2}{*}{ OR $(95 \% \mathrm{CI})$} & \multirow[b]{2}{*}{$p$-Value } \\
\hline & $\mathrm{n}$ & $\%$ & $\mathrm{n}$ & $\%$ & & \\
\hline AA & 220 & $58.7 \%$ & 215 & $57.3 \%$ & 1.00 (Reference) & \\
\hline $\mathrm{AC}$ & 96 & $25.6 \%$ & 98 & $26.1 \%$ & $1.04(0.74-1.47)$ & 0.8680 \\
\hline $\mathrm{CC}$ & 59 & $15.7 \%$ & 62 & $16.6 \%$ & $1.08(0.72-1.61)$ & 0.8024 \\
\hline $\mathrm{p}$ for trend & & & & & & 0.9266 \\
\hline \multicolumn{7}{|l|}{ Carrier comparison } \\
\hline $\mathrm{AA}+\mathrm{AC}$ & 316 & $84.3 \%$ & 313 & $83.4 \%$ & 1.00 (Reference) & \\
\hline $\mathrm{CC}$ & 59 & $15.7 \%$ & 62 & $16.6 \%$ & $1.06(0.72-1.57)$ & 0.8426 \\
\hline AA & 220 & $58.7 \%$ & 215 & $57.3 \%$ & 1.00 (Reference) & \\
\hline $\mathrm{AC}+\mathrm{CC}$ & 155 & $41.3 \%$ & 160 & $42.7 \%$ & $1.06(0.79-1.41)$ & 0.7673 \\
\hline \multicolumn{7}{|l|}{ Allelic frequency } \\
\hline Allele A & 536 & $71.5 \%$ & 528 & $70.4 \%$ & 1.00 (Reference) & \\
\hline Allele C & 214 & $28.5 \%$ & 222 & $29.6 \%$ & $1.05(0.84-1.32)$ & 0.6492 \\
\hline
\end{tabular}

OR: Odds ratio, CI: confidence interval; a based on Chi-square test with Yate's correction; *statistically significant.

Table V. Distribution of the enhancer of zeste homolog 2 (EZH2) rs3757441 genotypic and allelic frequencies among patients with bladder cancer and controls.

\begin{tabular}{|c|c|c|c|c|c|c|}
\hline \multirow{2}{*}{$\begin{array}{l}\text { rs3757441 } \\
\text { Genotypic frequency }\end{array}$} & \multicolumn{2}{|c|}{ Controls } & \multicolumn{2}{|c|}{ Patients } & \multirow[b]{2}{*}{ OR $(95 \% \mathrm{CI})$} & \multirow[b]{2}{*}{$p$-Value } \\
\hline & $\mathrm{n}$ & $\%$ & $\mathrm{n}$ & $\%$ & & \\
\hline TT & 165 & $44.0 \%$ & 169 & $45.1 \%$ & 1.00 (Reference) & \\
\hline CT & 168 & $44.8 \%$ & 172 & $45.9 \%$ & $1.00(0.74-1.35)$ & 0.9978 \\
\hline $\mathrm{CC}$ & 42 & $11.2 \%$ & 34 & $9.0 \%$ & $0.79(0.48-1.30)$ & 0.4264 \\
\hline $\mathrm{p}$ for trend & & & & & & 0.6259 \\
\hline \multicolumn{7}{|l|}{ Carrier comparison } \\
\hline $\mathrm{TT}+\mathrm{CT}$ & 333 & $88.8 \%$ & 341 & $91.0 \%$ & 1.00 (Reference) & \\
\hline $\mathrm{CC}$ & 42 & $11.2 \%$ & 34 & $9.0 \%$ & $0.79(0.49-1.27)$ & 0.3970 \\
\hline TT & 165 & $44.0 \%$ & 169 & $45.1 \%$ & 1.00 (Reference) & \\
\hline $\mathrm{CT}+\mathrm{CC}$ & 210 & $56.0 \%$ & 206 & $54.9 \%$ & $0.96(0.72-1.28)$ & 0.8256 \\
\hline \multicolumn{7}{|l|}{ Allelic frequency } \\
\hline Allele T & 498 & $66.4 \%$ & 510 & $68.0 \%$ & 1.00 (Reference) & \\
\hline Allele C & 252 & $33.6 \%$ & 240 & $32.0 \%$ & $0.93(0.75-1.15)$ & 0.5093 \\
\hline
\end{tabular}

OR: Odds ratio, CI: confidence interval; abased on Chi-square test with Yate's correction; *statistically significant.

For EZH2 rs41277434 and rs3757441, there was no distribution difference in the smoking, non-smoking, alcohol drinking, and non-alcohol drinking sub-groups (data not shown).

\section{Discussion}

EZH2 plays a role not only in cell-cycle regulation and proliferation, but also in tissue maturation and differentiation $(33,34)$. In the current study, we selected three polymorphic sites of the EZH2 gene, rs887569 (C to T), rs41277434 (A to $\mathrm{C}$ ) and rs3757441 ( $\mathrm{T}$ to $\mathrm{C}$ ), and clarified their associations with susceptibility for bladder cancer risk. EZH2 rs887569 is located in the 19th intron of the EZH2 gene, which was reported to bind with the PPAR- $\alpha / \mathrm{RXR}-\alpha$ complex. The PPAR- $\alpha /$ RXR- $\alpha$ complex can down-regulate EZH2 expression and trigger the cell to undergo programmed cell death and suppress cell proliferation (35). The significant findings showed that homozygous TT genotype, but not heterozygous CT of EZH2 rs887569 was associated with decreased susceptibility for bladder cancer in the investigated Taiwanese population, comparing with those with CC wildtype genotype (Table III). This novel finding in bladder cancer is supported by previous findings that the $\mathrm{T}$ allele of $E Z H 2$ rs887569 is associated with decreased susceptibility for colorectal cancer in another Han population in Shandong, an eastern province of China (23). In addition, TT genotype 
Table VI. Stratified distribution of the enhancer of zeste homolog 2 (EZH2) rs887569 genotypes among patients with bladder cancer and controls according to their smoking status.

\begin{tabular}{|c|c|c|c|c|c|c|}
\hline \multirow{2}{*}{$\begin{array}{l}\text { rs887569 } \\
\text { Genotypic frequency }\end{array}$} & \multicolumn{2}{|c|}{ Controls } & \multicolumn{2}{|c|}{ Patients } & \multirow[b]{2}{*}{ OR $(95 \% \mathrm{CI})$} & \multirow[b]{2}{*}{$p$-Value ${ }^{a}$} \\
\hline & $\mathrm{n}$ & $\%$ & $\mathrm{n}$ & $\%$ & & \\
\hline \multicolumn{7}{|l|}{ Smokers } \\
\hline $\mathrm{CC}$ & 78 & $41.9 \%$ & 83 & $41.3 \%$ & 1.00 (Reference) & \\
\hline $\mathrm{CT}$ & 90 & $48.4 \%$ & 96 & $47.8 \%$ & $1.00(0.66-1.53)$ & 0.9911 \\
\hline $\mathrm{TT}$ & 18 & $9.7 \%$ & 22 & $10.9 \%$ & $1.15(0.57-2.30)$ & 0.8307 \\
\hline$p$ for trend & & & & & & 0.9196 \\
\hline \multicolumn{7}{|l|}{ Non-smokers } \\
\hline $\mathrm{CC}$ & 72 & $38.1 \%$ & 86 & $49.4 \%$ & 1.00 (Reference) & \\
\hline $\mathrm{CT}$ & 92 & $48.7 \%$ & 78 & $44.8 \%$ & $0.71(0.46-1.10)$ & 0.1508 \\
\hline $\mathrm{TT}$ & 25 & $13.2 \%$ & 10 & $5.8 \%$ & $0.33(0.15-0.74)^{*}$ & $0.0098^{*}$ \\
\hline$p$ for trend & & & & & & $0.0164 *$ \\
\hline
\end{tabular}

OR: Odds ratio, CI: confidence interval; abased on Chi-square test with Yate's correction; *statistically significant.

of EZH2 rs887569 was associated with smaller tumor size and less differentiation of colorectal cancer (23). However, the authors also found that the $\mathrm{C}$ allele of rs3757441 was also associated with colorectal cancer risk, but similar results were not found in this study for bladder cancer (Table V). In another supporting report for the current study, the TT genotype of $E Z H 2$ rs887569 was also found to be associated with longer overall survival and lower mortality among patients with lung cancer (35).

To investigate the joint effects of genotypic and lifestyle factors, we firstly analyzed the interactions of $E Z H 2$ rs887569 genotype and with factors such as smoking and alcohol drinking. The genotypes of EZH2 rs887569 indeed had joint effects with individual smoking habits on bladder cancer susceptibility (Table VI): the protective T allele at $E Z H 2$ rs887569 may contribute to lower susceptibility for non-smokers, but not for smokers (Table VI). At the same time, no obvious joint effect of EZH2 rs887569 genotype with alcohol drinking habits on bladder cancer risk was observed in this population.

To sum up, to our knowledge, this is the first study to focus on $E Z H 2$ genotype and its synergistic effects with smoking or alcohol drinking habit on bladder cancer risk. The TT genotype of EZH2 rs887569 appears to be protective against bladder carcinogenesis, especially in non-smokers. The findings in bladder cancer should be validated in larger samples and other ethnicities. Molecular mechanisms and functional studies are also required.

\section{Acknowledgements}

The Authors declare no conflict of interest in regard to this study. This study was supported mainly by Taichung Armed Forces General Hospital to Dr. Liao (supporting number 105-A14) and partially by research grant from Taiwan Ministry of Health and
Welfare Clinical Trial and Research Center of Excellence (MOHW105-TDU-B-212-113019). We thank Hsin-Ting Li, ShiouTing Yen and colleagues in Tissue bank of China Medical University Hospital for their technical assistance.

\section{References}

1 Ferlay J, Soerjomataram I, Ervik M et al: GLOBOCAN 2012 v1.2, Cancer Incidence and Mortality Worldwide: IARC Cancer Base No. 11; 2014. Available from: http://globocan.iarc.fr. 2015.

2 Torre LA, Bray F, Siegel RL, Ferlay J, Lortet-Tieulent J and Jemal A: Global cancer statistics, 2012. CA Cancer J Clin 65: 87-108, 2015

3 Chang WS, Tsai CW, Ji HX, Wu HC, Chang YT, Lien CS, Liao WL, Shen WC, Tsai $\mathrm{CH}$ and Bau DT: Associations of cyclooxygenase 2 polymorphic genotypes with bladder cancer risk in Taiwan. Anticancer Res 33: 5401-5405, 2013.

4 Cohen SM, Shirai T and Steineck G: Epidemiology and etiology of premalignant and malignant urothelial changes. Scand J Urol Nephrol Suppl: 105-115, 2000.

5 Steineck G, Wiholm BE and Gerhardsson de Verdier M: Acetaminophen, some other drugs, some diseases and the risk of transitional cell carcinoma. A population-based case-control study. Acta Oncol 34: 741-748, 1995.

6 Chang $\mathrm{CH}$, Chiu CF, Wang $\mathrm{HC}$, Wu HC, Tsai RY, Tsai CW, Wang RF, Wang $\mathrm{CH}$, Tsou YA and Bau DT: Significant association of ERCC6 single nucleotide polymorphisms with bladder cancer susceptibility in Taiwan. Anticancer Res 29: 5121-5124, 2009.

7 Chang CH, Wang RF, Tsai RY, Wu HC, Wang CH, Tsai CW, Chang CL, Tsou YA, Liu CS and Bau DT: Significant association of XPD codon 312 single nucleotide polymorphism with bladder cancer susceptibility in Taiwan. Anticancer Res 29: 3903-3907, 2009.

8 Chang $\mathrm{CH}$, Chang CL, Tsai CW, Wu HC, Chiu CF, Wang RF, Liu CS, Lin CC and Bau DT: Significant association of an XRCC4 single nucleotide polymorphism with bladder cancer susceptibility in Taiwan. Anticancer Res 29: 1777-1782, 2009.

9 Fiskus W, Pranpat M, Balasis M, Herger B, Rao R, Chinnaiyan A, Atadja P and Bhalla K: Histone deacetylase inhibitors deplete enhancer of zeste 2 and associated polycomb repressive complex 
2 proteins in human acute leukemia cells. Mol Cancer Ther 5: 3096-3104, 2006.

10 Cao R, Wang L, Wang H, Xia L, Erdjument-Bromage H, Tempst P, Jones RS and Zhang Y: Role of histone H3 lysine 27 methylation in Polycomb-group silencing. Science 298: 10391043, 2002.

11 Martinez-Garcia E and Licht JD: Deregulation of $H 3 K 27$ methylation in cancer. Nat Genet 42: 100-101, 2010.

12 Cardoso C, Mignon C, Hetet G, Grandchamps B, Fontes M and Colleaux L: The human EZH2 gene: genomic organisation and revised mapping in $7 \mathrm{q} 35$ within the critical region for malignant myeloid disorders. Eur J Hum Genet 8: 174-180, 2000.

13 van Kemenade FJ, Raaphorst FM, Blokzijl T, Fieret E, Hamer KM, Satijn DP, Otte AP and Meijer CJ: Coexpression of BMI-1 and $\mathrm{EZH} 2$ polycomb-group proteins is associated with cycling cells and degree of malignancy in B-cell non-Hodgkin lymphoma. Blood 97: 3896-3901, 2001.

14 Yamada A, Fujii S, Daiko H, Nishimura M, Chiba T and Ochiai A: Aberrant expression of EZH2 is associated with a poor outcome and P53 alteration in squamous cell carcinoma of the esophagus. Int J Oncol 38: 345-353, 2011.

15 Collett K, Eide GE, Arnes J, Stefansson IM, Eide J, Braaten A, Aas T, Otte AP and Akslen LA: Expression of enhancer of zeste homologue 2 is significantly associated with increased tumor cell proliferation and is a marker of aggressive breast cancer. Clin Cancer Res 12: 1168-1174, 2006.

16 Bachmann IM, Halvorsen OJ, Collett K, Stefansson IM, Straume O, Haukaas SA, Salvesen HB, Otte AP and Akslen LA: EZH2 expression is associated with high proliferation rate and aggressive tumor subgroups in cutaneous melanoma and cancers of the endometrium, prostate, and breast. J Clin Oncol 24: 268273, 2006.

17 Choi JH, Song YS, Yoon JS, Song KW and Lee YY: Enhancer of zeste homolog 2 expression is associated with tumor cell proliferation and metastasis in gastric cancer. Apmis 118: 196202, 2010.

18 Cai GH, Wang K, Miao Q, Peng YS and Chen XY: Expression of polycomb protein EZH2 in multi-stage tissues of gastric carcinogenesis. J Dig Dis 11: 88-93, 2010.

19 Mattioli E, Vogiatzi P, Sun A, Abbadessa G, Angeloni G, D'Ugo D, Trani D, Gaughan JP, Vecchio FM, Cevenini G, Persiani R, Giordano A and Claudio PP: Immunohistochemical analysis of pRb2/p130, VEGF, EZH2, p53, p16(INK4A), p27(KIP1), p21(WAF1), Ki-67 expression patterns in gastric cancer. J Cell Physiol 210: 183-191, 2007.

20 Zhou Y, Du WD, Wu Q, Liu Y, Chen G, Ruan J, Xu S, Yang F, Zhou FS, Tang XF, Tang HY, Zuo XB, Zhang FY, Sun LD and Zhang XJ: EZH2 genetic variants affect risk of gastric cancer in the Chinese Han population. Mol Carcinog 53: 589-597, 2014.

21 Matsukawa Y, Semba S, Kato H, Ito A, Yanagihara K and Yokozaki H: Expression of the enhancer of zeste homolog 2 is correlated with poor prognosis in human gastric cancer. Cancer Sci 97: 484-491, 2006.

22 Kodach LL, Jacobs RJ, Heijmans J, van Noesel CJ, Langers AM, Verspaget HW, Hommes DW, Offerhaus GJ, van den Brink GR and Hardwick JC: The role of EZH2 and DNA methylation in the silencing of the tumour-suppressor RUNX3 in colorectal cancer. Carcinogenesis 31: 1567-1575, 2010.

23 Wang J, Ma ZB, Li K and Guo GH: Association between EZH2 polymorphisms and colorectal cancer risk in Han Chinese population. Med Oncol 31: 874, 2014.
24 Sudo T, Utsunomiya T, Mimori K, Nagahara H, Ogawa K, Inoue $\mathrm{H}$, Wakiyama S, Fujita $\mathrm{H}$, Shirouzu $\mathrm{K}$ and Mori $\mathrm{M}$ : Clinicopathological significance of EZH2 mRNA expression in patients with hepatocellular carcinoma. Br J Cancer 92: 17541758, 2005.

25 Toll AD, Dasgupta A, Potoczek M, Yeo CJ, Kleer CG, Brody JR and Witkiewicz AK: Implications of enhancer of zeste homologue 2 expression in pancreatic ductal adenocarcinoma. Hum Pathol 41: 1205-1209, 2010.

26 Kidani K, Osaki M, Tamura T, Yamaga K, Shomori K, Ryoke K and Ito H: High expression of EZH2 is associated with tumor proliferation and prognosis in human oral squamous cell carcinomas. Oral Oncol 45: 39-46, 2009.

27 Raman JD, Mongan NP, Tickoo SK, Boorjian SA, Scherr DS and Gudas LJ: Increased expression of the polycomb group gene, $E Z H 2$, in transitional cell carcinoma of the bladder. Clin Cancer Res 11: 8570-8576, 2005.

28 Pei JS, Chang WS, Hsu PC, Tsai CW, Hsu CM, Ji HX, Hsiao CL, Hsu YN and Bau DT: The association of FLAP endonuclease 1 genotypes with the risk of childhood leukemia. Cancer Genomics Proteomics 13: 69-74, 2016.

$29 \mathrm{Su} \mathrm{CH}$, Chang WS, Hu PS, Hsiao CL, Ji HX, Liao CH, Yueh TC, Chuang CL, Tsai CW, Hsu CM, Lane HY and Bau DT: Contribution of DNA double-strand break repair gene XRCC3 genotypes to triple-negative breast cancer risk. Cancer Genomics Proteomics 12: 359-367, 2015.

30 Hsu CM, Chang WS, Hwang JJ, Wang JY, Hsiao YL, Tsai CW, Liu JC, Ying TH and Bau DT: The role of apurinic/apyrimidinic endonuclease DNA repair gene in endometriosis. Cancer Genomics Proteomics 11: 295-301, 2014.

31 Hsia TC, Chang WS, Wang S, Shen TC, Hsiao WY, Liu CJ, Liang SJ, Chen WC, Tu CY, Tsai CW, Hsu CM and Bau DT: The contribution of interleukin-10 promoter genotypes to susceptibility to asthma in adults. In Vivo 29: 695-699, 2015.

32 Lo WJ, Chang WS, Hsu HF, Ji HX, Hsiao CL, Tsai CW, Yeh SP, Chen CM and Bau DT: Significant association of interleukin-10 polymorphisms with childhood leukemia susceptibility in Taiwan. In Vivo 30: 265-269, 2016.

33 Tonini T, D'Andrilli G, Fucito A, Gaspa L and Bagella L: Importance of EZH2 polycomb protein in tumorigenesis process interfering with the pathway of growth suppressive key elements. J Cell Physiol 214: 295-300, 2008.

34 Lee TI, Jenner RG, Boyer LA, Guenther MG, Levine SS, Kumar RM, Chevalier B, Johnstone SE, Cole MF, Isono K, Koseki H, Fuchikami T, Abe K, Murray HL, Zucker JP, Yuan B, Bell GW, Herbolsheimer E, Hannett NM, Sun K, Odom DT, Otte AP, Volkert TL, Bartel DP, Melton DA, Gifford DK, Jaenisch R and Young RA: Control of developmental regulators by Polycomb in human embryonic stem cells. Cell 125: 301-313, 2006.

35 Yoon KA, Gil HJ, Han J, Park J and Lee JS: Genetic polymorphisms in the polycomb group gene $E Z H 2$ and the risk of lung cancer. J Thorac Oncol 5: 10-16, 2010. 